\title{
Feds further limit scope of tax reforms affecting most doctors
}

Cite as: CMAJ 2017 November 6;189:E1375. doi: 10.1503/cmaj.109-5517

Posted on cmajnews.com on Oct. 18, 2017.

T he federal government will allow business owners to shelter up to $\$ 50000$ a year in passive investments inside their corporations, in a new tweak to controversial tax reforms announced Wednesday.

Up to $60 \%$ of doctors are incorporated and may be affected by the change. Finance Minister Bill Morneau said the new proposal will affect the top $3 \%$ of business owners, but provide others "a window so they can continue to have money inside their business."
Previously, the government had proposed to "neutralize" the tax advantage of holding investments inside a corporation. A person can be taxed as much as $53 \%$ on income they take out of a company, compared to rates as low as $15 \%$ if they hold the money in investments inside the business.

The government also proposed to close loopholes that allowed wealthy people to reduce their taxes by using corporations to divert income to family members or convert it into capital gains.
The proposed reforms met fierce opposition from doctors and other business owners who said they rely on these tax-saving strategies to grow savings for retirement or times when they are unable to work because of pregnancy or illness.

Earlier this week, the government backed down from capital gains reform, but said it would still limit income sprinkling to family members who don't contribute to a business.

Lauren Vogel, CMAJ 